\title{
Total carotenoids and antioxidant activity of fillets and shells (in natura or cooked) of "Vila Franca" shrimp (Litopenaeus Schmitti) in different intervals of storage under freezing
}

\author{
Carotenóides totais e atividade antioxidante dos filés e cascas (in natura ou \\ cozida) do camarão "Vila Franca" (Litopenaeus schmitti) em diferentes intervalos de \\ armazenamento sob congelamento
}

\author{
Giselda Macena Lira ${ }^{1 *}$, Ana Maria Queijeiro Lopez², Guilherme Oliveira Firmino³, \\ Suzan Diniz Santos ${ }^{3}$, Ranilson de Souza Bezerra ${ }^{3}$
}

${ }^{1}$ Universidade Federal de Alagoas/UFAL, Faculdade de Nutrição, Maceió, AL, Brasil

${ }^{2}$ Universidade Federal de Alagoas/UFAL, Instituto de Química e Biotecnologia, Maceió, AL, Brasil

${ }^{3}$ Universidade Federal de Pernambuco/UFPE, Departamento de Bioquímica, Recife, PE, Brasil

*Corresponding author: gmlira@superig.com.br

Received in June 10, 2016 and approved in October 18, 2016

\begin{abstract}
Shrimps are sources of carotenoids, astaxanthin is the predominant, responsible for their special and desirable properties, as well as for their instability under heat treatment during the domestic preparation, industrial processing or storage under freezing. These can cause discoloration and reduce the beneficial health properties. This study aimed to evaluate the effect of heat treatment and storage under freezing ( 0,45 and 90 days) on the levels of total carotenoids and stability of the antioxidant activity of ethanolic extracts of fillets and shells, raw and cooked, of the white shrimp ("Vila Franca") Litopenaeus schmitti (Burkenroad, 1938). The antioxidant ability of the extracts was evaluated using the radicals DPPH・ (2,2-diphenyl-1-picryl-hydrazyl) and ABTS+・ (2,2'-azino-bis (3-ethylbenzothiazoline-6 sulfonic acid), as well as by the iron reducing power (FRAP) test. The extracts of cooked or in natura shrimps (fillets and shells) represent dietary sources of carotenoids, displaying antioxidant activity through all the tested methods, after heat treatment and storage under freezing. The antioxidant activity of the extracts was superior to the one of ascorbic acid, mainly in the cooked fillet and shells. The samples of shrimp shells seemed a valuable source of carotenoids, whose antioxidant activity was verified even 90 days after freezing, and can be used in food products as functional natural supplement, adding value to this waste.
\end{abstract}

Index terms: Free radicals; functional food; biomolecules oxidation.

\section{RESUMO}

Os camarões são fontes de carotenóides, sendo a astaxantina o predominante, responsáveis por suas propriedades especiais e desejáveis, e também a causa da sua instabilidade pelo tratamento térmico durante o preparo doméstico, processamento industrial ou armazenamento sob congelamento, que pode causar descoloração e redução de suas propriedades benéficas à saúde. Este trabalho visou avaliar o efeito do tratamento térmico e armazenamento sob congelamento (0, 45 e 90 dias) nos teores de carotenóides totais e na estabilidade da atividade antioxidante dos extratos etanólicos de filé e cascas, cruas ou cozidas, de camarão "Vila Franca" Litopenaeus schmitti (Burkenroad, 1938). A capacidade antioxidante dos extratos foi avaliada utilizando os radicais DPPH• (2,2-difenil-1-picril-hidrazila) e ABTS+• (2,2'-azino-bis-(3etilbenzotiazolina-6- acido sulfônico), bem como pelo teste do poder redutor do ferro (FRAP). Os extratos do camarão cozido ou in natura (filé e cascas), representam fontes dietéticas de carotenóides, exibindo atividade antioxidante através de todos os métodos testados, após o tratamento térmico e armazenamento sob congelamento. A atividade antioxidante dos extratos foi superior a de ácido ascórbico, principalmente no filé e cascas cozidos. As amostras de cascas de camarão parecem uma valiosa fonte de carotenóides, cuja atividade antioxidante foi verificada até 90 dias após o congelamento, e pode ser utilizado nos produtos alimentares como suplemento natural funcional, agregando valor a esses resíduos.

Termos para indexação: Alimentos funcionais; radicais livres; oxidação de biomoléculas.

\section{INTRODUCTION}

Through a series of oxidation reactions (Pashkow; Watumull; Campbell, 2008), free radicals in excess can react and cause oxidative damage to cellular components such as proteins, lipids, lipoproteins and deoxyribonucleic acid (DNA) (Lobo et al., 2010; Singh; Devi; Gollen, 2015), being one of the causes of degenerative diseases and aging (Valko et al., 2006). However, oxidation of biomolecules can be inhibited by suitable amounts of antioxidants present in balanced daily diet (Bose; Agrawal, 2007; Thomson et al., 2007). 
Shrimps are sources of carotenoids - isoprenoids with a long polyene chain containing 3-15 conjugated double bonds, responsible for their special and desirable properties, as well as for their instability under heat treatment during the domestic preparation, industrial processing (Boon et al., 2010) or storage under freezing (Rodriguez-Amaya, 2004). These can cause discoloration and reduce the nutritional value and beneficial health properties of food containing carotenoids (Li et al., 2013).

Astaxanthin (3,3'--dihydroxy- $\beta$, $\beta$-carotene-4,4'dione) is the predominant carotenoid present in shrimps (fillet and shells), lobsters, fishes (trout and salmon) and some microorganisms (Suh; Joo; Lee, 2006; Niamnuy; Devahastin; Soponronnarist, 2008b; Nguyen, 2013), with a red-orange color (Miao et al., 2006; Kusdiyantini et al., 1998; Armenta; Guerrero-Legarreta, 2009). It removes the singlet oxygen $\left({ }^{1} \mathrm{O}_{2}\right)$ and the peroxyl radicals $\left(\mathrm{H}_{2} \mathrm{O}_{2}\right)$ from the medium in a more efficient way than do $\beta$-carotene (10 times more), canthaxanthin and zeaxanthin (Palozza; Krinsky, 1992), and exceeds (500 times more) the antioxidant effect (Higuera-Ciapara; Félix-Valenzuela; Goycoolea, 2006; Hussein et al., 2006b) of vitamins C and E (Palozza; Krinsky, 1992; Suh; Joo; Lee, 2006). Thus, it prevents tissues (such as the skin) from being damaged (Chong et al., 2007; Lyons; O'Brien, 2002), or protects the body against diseases like diabetes (Manabe et al., 2008; Kim; Kim; Yokozawa, 2009), neoplasms (Bertram; Vine, 2005), hypertension (Hussein et al., 2006a) and atherosclerosis (Setnikar; Senin; Rovati, 2005), among others. However, due to their conjugated double bonds structure, astaxanthin is sensitive to light, temperature, acidity, and oxidation reactions (Ambrósio; Campos; Faro, 2006).

The white shrimp ("Vila Franca" or "caboclo" or "legitimate") [Litopenaeus schmitti (= Penaeus schmitti) (Burkenroad, 1938) (Crustacea: Decapoda: Penaeidae)], occurs in the western Atlantic, from the West Indies $\left(23^{\circ} 30^{\circ} \mathrm{N}\right)$ to southern Brazil $\left(29^{\circ} 45^{\circ} \mathrm{S}\right)$, and because of its size (about $20 \mathrm{~cm}$ long) and flavor, it is a highlighted crustacean in the cuisine of northeastern Brazil. It is handexploited, but with significant commercial interest (Santos et al., 2012). Once there is no scientific information about the total carotenoid content and antioxidant stability of this cooked or in natura shrimp, before or after freezing, it was evaluated in this study.

\section{MATERIAL AND METHODS}

\section{Harvesting and preparation of samples}

A batch of $2.0 \mathrm{~kg}$ of white shrimp (Litopenaeus schmitti), from the coastline (geographic coordinates $8^{\circ} 8^{\prime} 12^{\prime \prime S}$ and $10^{\circ} 29^{\prime} 12^{\prime \prime S}$ ) of Maceió-Alagoas/Brazil, where the water reaches high salinity (35.5 psu) and medium temperature $27.8^{\circ} \mathrm{C}$ (Araújo, 2006), was acquired in May 2013, soon after collected. The samples were placed in plastic bags, kept in cooler box with ice and immediately transported to the laboratory.

This batch was split into two groups of $1.0 \mathrm{Kg}$. Group "I" was formed by fresh samples and group "II" was subjected to cooking in $1 \mathrm{~L}$ water during $17 \mathrm{~min}$ at $99.4{ }^{\circ} \mathrm{C}$. In both groups, the residue of the head and intestines of the shrimps were removed. Only the fillets and shells from the exoskeleton carapace, plus tail and legs, were used. As the mass of fillets for the analyzes was $30 \mathrm{~g}$ (in natura and after cooking), it was estimated that the amount of acquired sample per group $(1 \mathrm{Kg})$ was sufficient.

Then, the mass of appropriate aliquots of the in nature (group I) and cooked (group II) samples of the fillets $(30 \mathrm{~g})$ and the shells $(15 \mathrm{~g})$ randomically collected were measured and identified for analysis. The remaining samples (in natura and cooked) were packed in aseptic plastic bags, identified and stored in plastic containers in the freezer at $-17^{\circ} \mathrm{C}\left( \pm 1{ }^{\circ} \mathrm{C}\right)$, until the moment of the analysis $(0,45$ and 90 days under freezing). The "time zero" samples were processed at the same day, whilst the others were stored under freezing until the interval settled for the analysis (45 or 90 days).

\section{Extraction of carotenoids}

The extracts were subjected to chemical analysis in quadruplicate.

\section{Shrimp fillet}

The carotenoid pigments were extracted from the fillets samples $(30 \mathrm{~g})$ through homogenization with $92.8^{\circ}$ ethanol $(100 \mathrm{~mL})$ in a blender during $5 \mathrm{~min}$. The commercial ethanol $\left(92.8^{\circ}\right)$ was used since it enables a better extraction with less cost and it is a less toxic solvent (Santos et al., 2012).

Each crude extract was centrifuged at 10,000 rpm at $4{ }^{\circ} \mathrm{C}$ for $10 \mathrm{~min}$, and the supernatant (liquid phase) was stored in amber bottles, while the precipitate $(16 \mathrm{~g})$ was re-homogenized for 5 min with commercial ethanol until the complete removal of pigments $(56 \mathrm{~mL})$. The second supernatant was added to the first and the mixture was filtered (filter paper) before the final collection on a second amber vial. To avoid possible oxidation due to contact with oxygen from the air, nitrogen gas was sprayed into the vial before being closed. Then it was stored in a freezer at $-17^{\circ} \mathrm{C}\left( \pm 1^{\circ} \mathrm{C}\right)$ until the next day when the total carotenoids and antioxidant activity were determined. 


\section{Shrimp waste (shells, tail and paws)}

The carotenoid pigments were extracted from the shrimp waste $(15 \mathrm{~g})$ through homogenization with $92.8^{\circ}$ ethanol $(100 \mathrm{~mL})$ in a blender during $5 \mathrm{~min}$ (Santos et al., 2012). Each crude extract was then centrifuged (10,000 $\mathrm{rpm} / 4{ }^{\circ} \mathrm{C}, 10 \mathrm{~min}$ ), and the supernatant (liquid phase) stored in amber bottles. Two more extractions were carried out with the pellet, until no pink pigment was seen - the first from $12 \mathrm{~g}$ of it, with the addition of $40 \mathrm{~mL}$ ethanol, and the second from $10 \mathrm{~g}$ of the remaining pellet, adding $30 \mathrm{~mL}$ of ethanol. The same procedures described above for the fillet samples were used.

\section{Determination of carotenoids content}

The absorbance of $1 \mathrm{~mL}$ of each ethanolic extract was measured at $470 \mathrm{~nm}$ using a spectrophotometer. The "blank" reference corresponded to $1 \mathrm{~mL}$ of ethanol (Schiedt and Liaaen-Jensen, 1995). The concentration of carotenes in the extract was determined using the following equation (Equation 1), wherein " $\mathrm{A}$ " is the absorbance at $470 \mathrm{~nm}$, "vol" is the volume (mL) used in the extraction of carotenoids and " $\mathrm{A}$ " $1 \%$ " is the absorption coefficient for $1 \%$ of the mixture of unknown carotenes at 2500 :

$\operatorname{Carotenoids}(\mathrm{mg})=\frac{\mathrm{A} \times \mathrm{vol} \times 1000}{\mathrm{~A}_{1 \mathrm{~cm}}^{1 \%} \times 100}$

\section{Tests for determination of antioxidant activity}

\section{Test of DPPH•}

The sequestration of the DPPH radical was determined according to the method described by Je et al. (2009), mixing $100 \mu \mathrm{L}$ of ethanolic solution of $0.15 \mathrm{mM}$ DPPH and $100 \mu \mathrm{L}$ of the carotenoid extracts obtained as described in 2.2. The absorbance of the mixtures, after $30 \mathrm{~min}$ in the dark, was measured at $517 \mathrm{~nm}$ using a microplate reader from Biorad ${ }^{\circledR}$ and software MMP6. The scavenging activity was calculated using the following equation (Equation 2):

Activity $(\%)=100 \times[1-($ Sample - blank $) /$ Control $]$

The absorbance of the "blank" reference corresponds to the mixture of $100 \mu \mathrm{L}$ of ethanol and $100 \mu \mathrm{L}$ of total carotenoids extracts, while the "control" absorbance corresponded to the mixture of $100 \mu \mathrm{L}$ ethanolic, 0.15 $\mathrm{mM}$ DPPH and $100 \mu \mathrm{L}$ ethanol p.a.

\section{Test of the $\mathrm{ABTS}^{+} \bullet$ radical}

The antioxidant activity of the extracts, as well as of the ascorbic acid ethanolic solutions (100$\left.275 \mu \mathrm{g} \cdot \mathrm{mL}^{-1}\right)$ on the radical $\mathrm{ABTS}^{+} \bullet\left(2,2^{\prime}\right.$-azino-bis-(3etilbenzotiazolina-6- acido sulfônico), was measured according to Wang and Xiong (2005). The ABTS ${ }^{+}$stable radical originally is a blue-green chromophore. Its stock solution was prepared by the reaction of equal volumes of $2.45 \mathrm{mM}$ potassium persulphate and $7 \mathrm{mM} \mathrm{ABTS}^{+} \bullet$, which, after 12 hours at room temperature and dark, gets a dark blue-green color. This solution was diluted in $0.2 \mathrm{M}$ sodium phosphate buffer (PBS), $\mathrm{pH} 7.4$, with an absorbance of $0,70 \pm 0.02$ at $734 \mathrm{~nm}$. Then, $20 \mu \mathrm{L}$ of the ethanolic extracts or ascorbic acid solution in different concentrations, were added to $1980 \mu \mathrm{L}$ of the $\mathrm{ABTS}^{+}$• diluted stock solution. After vigorous homogenization for $30 \mathrm{~s}$, the absorbance of the mixtures of reaction after 5 min (room temperature, dark) was measured at 734 $\mathrm{nm}$. From the obtained absorbance, the percentage of inhibition (PI) was calculated according to the following equation (Equation 3):

$$
\mathrm{ABTS}^{+} \cdot \mathrm{PI}=\frac{\mathrm{Abs}_{\mathrm{A}}-\mathrm{Abs}_{\mathrm{B}} \times 100}{\mathrm{Abs}_{\mathrm{B}}}
$$

In which, AbsA corresponds to the absorbance of the ethanolic extracts with $\mathrm{ABTS} \bullet+$ radical after 5 min of reaction, whilst $\mathrm{AbsB}$ corresponds to the absorbance of the diluted solution of $\mathrm{ABTS}^{+} \bullet$.

\section{Assay of the ferric reducing antioxidant power (FRAP)}

The method used was the one described by Ahmadi, Kadivar and Shahedi (2007). Therefore, 200 $\mu \mathrm{L}$ ethanolic extracts or ascorbic acid ethanolic solutions (10-100 $\mu \mathrm{g} \mathrm{mL}^{-1}$ ) were mixtured with $200 \mu \mathrm{L}$ phosphate buffer $(0.2 \mathrm{M}, \mathrm{pH} 6.6)$ and $200 \mu \mathrm{L}$ of potassium ferricyanide $(1 \% \mathrm{w} / \mathrm{v})$. The mixture was incubated during $20 \mathrm{~min}\left(50{ }^{\circ} \mathrm{C}\right)$ until the addition of $200 \mu \mathrm{L}$ trichloroacetic acid $(10 \% \mathrm{w} / \mathrm{v})$ for inhibiting the reaction. Then, it was centrifuged at $3000 \mathrm{~g}$ for $10 \mathrm{~min}$ and an aliquot of 125 $\mu \mathrm{L}$ of the supernatant was collected and mixture with $125 \mu \mathrm{L}$ of distilled water and $20 \mu \mathrm{L}$ of ferric chloride solution $(0.1 \% \mathrm{w} / \mathrm{v})$ in a well of Elisa microplate. After 10 $\mathrm{min}$ at room temperature, the absorbance of the reaction was measured at $700 \mathrm{~nm}$ using a microplate ELISA reader and the MPM 6 Biorad $^{\circledR}$ software. As higher was the absorbance, higher the reducing antioxidant power evaluated. In the "blank" reference, distilled water was used instead of the ethanolic extract. 


\section{Statistical analysis}

The data were subjected to analysis of variance and the means were compared by Tukey test at the level of $5 \%$ of probability. To detect the possible relationship between methods of antioxidant activity determination, the Pearson correlation was estimated. The analyzes were performed using the statistical softwares Genes (Cruz, 2013) or SAS (Statistical Analyses System), version 9.1 (SAS, 2006).

\section{RESULTS AND DISCUSSION}

\section{Total carotenoids}

The total carotenoid content of the studied samples (in natura or cooked, time "zero" or after 45 and 90 days of storage under freezing), are shown in Table 1.

The average concentrations of the carotenoids in fillet samples (raw and cooked), in each interval studied, were not statistically different $(\mathrm{p}<0.05)$ amongst them. So, apparently the heat treatment did not affect the stability of carotenoids in fillets of "Vila Franca" shrimp, which is a positive feature since this is the most consumed part of the shrimps and with the highest nutritional value for the human diet.

These results corroborate the ones obtained in the studies of Dutra et al. (2012), who worked with Murcote tangerine juice subjected to heat treatment ( 88 and $100{ }^{\circ} \mathrm{C}$ by 16 e $44 \mathrm{~s}$ respectively), and observed that none significant difference occurred in its content of lutein, zeaxanthin, $\beta$-cryptoxanthin and $\beta$-carotene. Also, according to Choubert, Brisbarre and Baccaunaud (2011), due to the degradation of carotenoids, the salmon frozen storage time is often limited by oxidation and discoloration of the fish. However, the content of carotenoids was not reduced in whole rainbow trout (Oncorhynchus mykiss) previously fed with astaxanthin (100 $\left.\mathrm{mg} \mathrm{L}^{-1}\right)$ and canthaxanthin (80 $\left.\mathrm{mg} \mathrm{L^{-1 }}\right)$, when they were frozen stored $\left(-18^{\circ} \mathrm{C}\right)$ for 6 months, probably because the protection against oxidation is on the skin of these fishes. On the other hand, studies of Andersen et al. (1990) using wild salmon and rainbow trout from aquaculture, both packed in transparent vacuumskin packaging during storage of 6 months under freezing chamber $\left(-17^{\circ} \mathrm{C}\right)$, showed that fillets of rainbow trout prior to storage had higher content of carotenoids identified as astaxanthin (9.1 $\mathrm{mg} \mathrm{kg}^{-1}$ ) than wild salmon fillets (4.9 mg $\mathrm{kg}^{-1}$ prior to storage), although in the last ones it remained virtually constant during the six months, but decreased along the time in the first ones. Rancidity developed faster in fillets of wild salmon as compared to the ones of rainbow trout. This suggests the role of astaxanthin as a sacrificial protector against radical processes.

In the present work, the carotenoid content in raw shells was 7 times higher than in the raw fillets, and regarding to the storage under freezing, the carotenoids of the raw shells remained markedly more stable, with a concentration $c a$. 7.25 to 8.56 times higher than in the frozen raw fillet. Additionally, the cooking decreased the total content of carotenoids of shrimp shells in $15 \%$ at all intervals of storage analyzed, although it still remained high compared to the fillets. Despite the loss resulting from the cooking, the shells still represent an important source of carotenoids. Sowmya et al. (2014) also reported that shrimp waste is the major source of carotenoid astaxanthin. Seabra et al. (2014) found $42.74 \mu \mathrm{g} / \mathrm{g}$ of total carotenoids in fresh waste of Pacific white shrimp (Litopenaeus vannamei), which is a concentration higher than in the present study.

The shrimp shells, with very low commercial value, represent a source of environmental pollution, and generate additional costs for its disposal, reducing the profit margin of the production system. They are usually discarded by the packing houses, without any technological use and correspond to $28.6 \%$ of the waste crustacean (Meyers, 1986). Shrimp waste is processed as animal feed and as

Table 1: Total content of carotenoids $\left(\mu \mathrm{g} \mathrm{mL} \mathrm{mL}^{-1}\right)$ in fillet and shells of "Vila Franca" shrimp (Litopenaeus schmitti) (in natura or cooked), from time "zero" or from the storage under different freezing intervals (45 and 90 days).

\begin{tabular}{cccc}
\hline \multirow{2}{*}{ Shrimp Samples } & \multicolumn{3}{c}{ Total Carotenoids $\left(\mu \mathrm{g} \mathrm{mL}{ }^{-1}\right)$} \\
\cline { 2 - 4 } & 0 & 45 & 90 \\
\cline { 2 - 4 } & $0.5720 \pm 0.050 \mathrm{cA}$ & $0.4993 \pm 0.011 \mathrm{cA}$ & $0.3480 \pm 0.030 \mathrm{cB}$ \\
Raw fillet & $0.5640 \pm 0.010 \mathrm{cA}$ & $0.5403 \pm 0.013 \mathrm{cA}$ & $0.4050 \pm 0.010 \mathrm{cB}$ \\
cooked fillet & $4.1533 \pm 0.040 \mathrm{aA}$ & $3.5133 \pm 0.037 \mathrm{aB}$ & $2.9800 \pm 0.151 \mathrm{aC}$ \\
raw shells & $3.5393 \pm 0.150 \mathrm{bA}$ & $3.0827 \pm 0.108 \mathrm{bB}$ & $2.5450 \pm 0.017 \mathrm{bC}$ \\
cooked shells & & \multicolumn{3}{c}{ Creezing time (days) } \\
\hline
\end{tabular}

* Averages followed by the same lower case letter in the same column, and capitalized case letter in equal lines, do not differ statistically at $5 \%$ probability (Tukey test). 
raw material protein in diets for aquaculture (Sudaryono; Tsvetnenko; Evans, 1996). To increase the market value of this disposal, many alternatives have been applied for use of this material: proteins and amino acids (Mandeville; Yaylayan; Simpson, 1992), dyes (Nguyen, 2013), flavoring (Pan, 1990), chitin and chitosan (Coward-Kelly; Agbogbo; Holtzapple, 2006).

As natural carotenoids have higher antioxidant properties than the synthetic ones (Levin; Yeshurun; Mokady, 1997), and the demand of consumers for natural products is increasing, the use of shells shrimps in the preparation of functional food represent an alternative of great added value for such residue.

Perdigão et al. (1995), reported that specimens of raw shellfish shells resulted in a minimal extraction pigments compared to the boiled samples. Moreover, Becerra et al. (2014) found similar results to the ones of the present study - after 15 min of boilling, the content of astaxanthin in the shrimps was significantly reduced in comparison to that in raw crustacean, and the authors concluded that this decrease could be related to the degradation and partial solubilization of the carotenoprotein complex. In this regard, Niamnuy, Devahastin and Soponronnarit (2008b) found a significant reduction on the protein (myofibrillar, sarcoplasmic and stromatic) content in cooked shrimp, suggesting that some of these could have suffered denaturation and degradation.

Compared to time zero, the concentration of total carotenoids in the treatments of raw and cooked fillet, after 45 days under freezing, also showed no significant difference $(p<0.05)$. After 90 days of freezing, however, statistically significant losses $(\mathrm{p}<0.05)$, respectively of $39 \%$ and $28 \%$, were observed in this content. In relation to the total carotenoid content in shells (raw and cooked) stored for 45 days under freezing, there are significant losses $(\mathrm{p}<0.05)$ of $15.41 \%$ and $13 \%$ respectively. After 90 days under freezing, the losses reached $28.6 \%$ and $13 \%$, respectively. Becerra et al. (2014) observed a 74\% reduction in the level of astaxanthin after 60 days of storage of shrimps salted under the sun as compared to the content found at time zero.

Some studies suggest that to obtain the beneficial effects of astaxanthin is needed a daily intake of about $4 \mathrm{mg}$ of the carotenoid (Parisi et al., 2008; Satoh et al., 2009). The astaxanthin capsules commercialized in some countries have concentration varying between 4 and $20 \mathrm{mg}$ (Seabra; Pedrosa, 2010). Considering the total content of carotenoids on $15 \mathrm{~g}$ samples of raw shells of "Vila Franca" shrimp, their level corresponded to $0.498 \mathrm{mg}(4,15 \mu \mathrm{g} \mathrm{X}$ $120 \mathrm{~mL}$ extract), i.e., $33.2 \mu \mathrm{g} \mathrm{g}^{-1}$ shrimp waste, so that about $675 \mathrm{~g}$ of these shrimp shells could create a capsule with a highest dose of astaxanthin $(90 \%$ of the content of carotenoids in shell). Thus, these products can be used as natural food additives for human or animal use.

\section{Tests for determination of antioxidant activity}

There is no universal method by which the antioxidant activity can be accurately quantified (Prior; Xianli; Schaich, 2005; Frankel; Meyer, 2000). This fact establishes the need to evaluate such parameter by different techniques, such as the $\mathrm{DPPH} \bullet$ and $\mathrm{ABTS}^{+}$- radicals scavenging assays or the Ferric Reducing Antioxidant Power (FRAP) test, which already have been used with shrimp protein hydrolysates (Binsan et al., 2008; Benjakul et al., 2009; Faithong et al., 2010).

\section{Test of DPPH • radical}

The ability of the studied extracts as scavengers of free radical DPPH $\bullet$, expressed as a percentage of the antioxidant activity is shown in Table 2. As for the total

Table 2: Antioxidant activity (\%) determined according to the DPPH $\bullet$ radical free scavenging assay, of carotenoid extracts of fillet and shells of "Vila Franca" shrimp (Litopenaeus schmitti) (in natura or cooked), from time "zero" or from the storage under different freezing intervals (45 and 90 days).

\begin{tabular}{cccc}
\hline \multirow{2}{*}{ Samples } & \multicolumn{3}{c}{ Antioxidant activity (\%) (DPPH•) } \\
\cline { 2 - 4 } & 0 & \multicolumn{3}{c}{ Freezing time (days) } \\
\cline { 2 - 4 } & $68.970 \pm 1.290 \mathrm{bA}$ & $66.094 \pm 3.840 \mathrm{abA}$ & $64.289 \pm 3.510 \mathrm{aA}$ \\
Raw fillet & $67.018 \pm 1.980 \mathrm{bA}$ & $65.052 \pm 3.870 \mathrm{bA}$ & $63.755 \pm 3.150 \mathrm{aA}$ \\
Cooked fillet & $79.841 \pm 4.520 \mathrm{aA}$ & $72.669 \pm 3.100 \mathrm{aA}$ & $60.379 \pm 3.192 \mathrm{aB}$ \\
Raw shells & $64.274 \pm 3.220 \mathrm{bA}$ & $62.806 \pm 2.190 \mathrm{bA}$ & $50.778 \pm 6.740 \mathrm{bB}$ \\
Cooked shells &
\end{tabular}

* Averages followed by the same lower case letter in the same column, and capitalized case letter in equal lines, do not differ statistically at $5 \%$ probability (Tukey test). 
content of carotenoids, the antioxidant activity of raw and cooked fillet in different intervals under freezing storage showed no statistically significant differences $(\mathrm{p}<0.05)$ amongst them, indicating no interference of heat treatment. Regarding to "time zero", the capacity of extracts from raw or cooked fillet, after 45 and 90 days under freezing, as scavenging of the free radical DPPH, showed no statistical difference $(\mathrm{p}<0.05)$.

Raw shrimp shells, in comparison to raw fillets of "Vila Franca" shrimp, according to the DPPH test, had an increase of its antioxidant activity of only $13.6 \%$, and this arise $c a .16 \%$ in cooked fillet.

Meenata et al. (2011) found strong DPPHscavenging activity in shrimp residues. After cooking the shells, there was a decrease of $19.5 \%$ in comparison to the in natura samples, but no significant difference $(p<0.05)$ was observed regarding to the antioxidant activity of the extracts of raw or cooked fillets. Freezing this material for 90 days decreased the antioxidant activity by approximately $24 \%$ in relation to the time zero. But the frozen cooked material, even after 90 days, still retained the free DPPH $\bullet$ radical scavenging activity in percentage higher to $50 \%$.

\section{Test of $\mathrm{ABTS}^{+} \bullet$ radical}

The ability of the extracts of carotenoids as scavengers of free $A B T S^{+} \bullet$ radical, expressed as a percentage is shown in Table 3 . There was no statistically significant difference $(p>0.05)$ between scavenging activity percentages of the extracts obtained at time zero of in natura fillets in relation to shells (in natura or cooked). After 45 days under freezing, however, significant reductions were observed $(\mathrm{p}<0.05)$, in this activity with respect to time zero, corresponding to $26.03 \%$ for crude fillet; $16.40 \%$ for the cooked fillet; $24.28 \%$ for the cooked shrimp shells and $22.37 \%$ for the in natura shells. These values differ from those expressed by DPPH• test, but are similar to ones of other research where freezing range time could interfere in the content of carotenoids and antioxidant activity if vacuum packaging material and the preparation of the fish skin was not specific to prevent lipid oxidation in long time storage (Andersen et al., 1990).

Regarding the comparison of the extracts obtained from raw fillet and cooked shells stored under freezing for 45 days, there was no significant difference $(p<0.05)$ in $\mathrm{ABTS}^{+} \bullet$ sequester activity, but the extracts of the cooked fillets and raw shells showed significant difference between them $(\mathrm{p}<0.05)$.

The $\mathrm{ABTS}^{+} \bullet$ sequester activity of the extracts obtained from samples under 90 days of freezing suffered significant losses $(\mathrm{p}<0.05)$ from that of extracts obtained at time zero, it means, reduction of $76.37 \%$ in raw fillet, $60.72 \%$ in cooked fillet, $76.76 \%$ in raw shells and $69.97 \%$ in cooked shells, highlighting the cooked fillet, which presented the lowest percentage of losses $(60.72 \%)$. This suggests that the usual form of shrimp consumption provides some antioxidant activity of its bioactive compounds.

When the results of this antioxidant activity, measured by $\mathrm{ABTS}^{+} \cdot$ sequestration, were expressed in terms of equivalents $\mu \mathrm{g} \mathrm{mL} \mathrm{m}^{-1}$ ascorbic acid antioxidant activity ( standard curve $\mathrm{y}=0.0046 \mathrm{x}-0.008 ; \mathrm{R}^{2}=0.9903$ ), the same profile was observed, and to a content of 4.153 $\mu \mathrm{g} \mathrm{mL}^{-1}$ total carotenoids (Table 1 ), the antioxidant activity obtained was similar to the one of $200 \mu \mathrm{g} \mathrm{mL} \mathrm{m}^{-1}$ ascorbic acid (Table 4).

Table 3: Antioxidant activity (\%) determined according to the ABTS $\bullet$ radical assay, of carotenoid extracts of fillet and shells of "Vila Franca" shrimp (Litopenaeus schmitti) (in natura or cooked), from time "zero" or from the storage under different freezing intervals (45 and 90 days).

\begin{tabular}{cccc}
\hline & \multicolumn{3}{c}{ Antioxidant activity (\%) (ABTS ${ }^{+}$) } \\
\cline { 2 - 4 } Samples & 0 & Freezing time (days)* & 90 \\
\cline { 2 - 4 } & $42.41 \pm 5.17 \mathrm{aA}$ & $31.37 \pm 7.00 \mathrm{abA}$ & $10.02 \pm 1.81 \mathrm{aB}$ \\
Raw fillet & $33.35 \pm 3.03 \mathrm{bA}$ & $27.88 \pm 2.39 \mathrm{aA}$ & $13.10 \pm 3.10 \mathrm{bB}$ \\
Cooked fillet & $45.23 \pm 2.21 \mathrm{aA}$ & $35.11 \pm 2.70 \mathrm{bB}$ & $10.51 \pm 3.19 \mathrm{aC}$ \\
Raw shells & $43.86 \pm 3.07 \mathrm{aA}$ & $33.21 \pm 1.93 \mathrm{abB}$ & $13.17 \pm 2.02 \mathrm{aC}$ \\
\hline
\end{tabular}

* Averages followed by the same lower case letter in the same column, and capitalized case letter in equal lines, do not differ statistically at $5 \%$ probability (Tukey test). 
Despite significant losses $(\mathrm{p}<0.05)$ of antioxidant activity in each extract obtained from the samples stored 90 days under freezing, the superiority of the antioxidant potential of them compared to ascorbic acid was observed mainly for the cooked fillet and shells, it means, for carotenoid contents of $0.405 \mu \mathrm{g} \mathrm{mL}^{-1}$ and $2.545 \mu \mathrm{g} \mathrm{mL}^{-1}$, respectively, corresponding antioxidant activities of ascorbic acid of $52 \mu \mathrm{g} \mathrm{mL}^{-1}$ and $53 \mu \mathrm{g} \mathrm{mL}^{-1}$ were obtained (Table 4).

Results from Sowmya and Sachindra (2012) evidenced the high antioxidant activity of astaxanthin extracted from shrimp waste. Weeratunge and Perera (2016) also reported that the carotenoid astaxanthin exhibits a high degree of antioxidant activity. These results confirm the literature information that the antioxidant potential of astaxanthin- predominant carotenoid of shrimps, exceeds the antioxidant benefits of vitamin C (Palozza; Krinsky, 1992).

\section{Ferric reducing antioxidant power (FRAP) assay}

The FRAP results for the extracts of fillet and shells of "Vila Franca" shrimp are shown in Table 5. The cooked shrimp shells showed a statistically significant decrease $(\mathrm{p}<0.05)$ of the FRAP after different freezing intervals ( 0,45 and 90 days), i.e., $28.1 \%, 47.91 \%$ and $40 \%$, respectively. Then, temperature and interval of freezing-storage could cause physico-chemical changes in compounds responsible for this antioxidant activity.

The cooked fillet, in turn, also showed a reduction of this effect in relation to the raw fillet at time zero ( $\cong 8 \%)$ and after 90 days of frozen storage $(\cong 6.9 \%)$, although at 45 days of storage that potential was not statistically changed by cooking. In fact, the FRAP decreased over the freezing time for all treatments, but these losses were only statistically significant $(\mathrm{p}<0.05)$ in extracts of cooked shrimp shells studied 45 days after freezing $(48.55 \%$ reduction), and from the crude shells 45 and 90 days after freezing, i.e., respectively $28.99 \%$ and $37.86 \%$.

When these results were expressed in terms of equivalent $\mu \mathrm{g} \mathrm{mL} \mathrm{m}^{-1}$ ascorbic acid antioxidant activity (standard curve $\mathrm{y}=0.0078 \mathrm{x}-0.0234 ; \mathrm{R}^{2}=0.998$ ), the same profile was observed, it means, for a carotenoid content of $4.1533 \mu \mathrm{g} \mathrm{mL}^{-1}$ (Table I), the equivalent FRAP expressed in terms of ascorbic acid was $46.27 \mu \mathrm{g} \mathrm{mL}^{-1}$ (Table 6).

Table 4: Antioxidant activity in terms of $\mu \mathrm{mL}^{-1}$ equivalents of ascorbic acid, determined according to the ABTS $\mathrm{S}^{+}$ radical assay, of carotenoid extracts of fillet and shells of "Vila Franca" shrimp (Litopenaeus schmitti) (in natura or cooked), from time "zero" or from the storage under different freezing intervals (45 and 90 days).

\begin{tabular}{cccc}
\hline \multirow{2}{*}{ Samples } & \multicolumn{3}{c}{ Antioxidant activity $\left(\mathrm{ABTS}^{+} \bullet\right.$ ) in ascorbic acid equivalents $\left(\mu \mathrm{g} \mathrm{mL}^{-1}\right)$} \\
\cline { 2 - 4 } & 0 & freezing time (days) \\
\cline { 2 - 4 } & $187 \pm 24 \mathrm{aA}$ & $136 \pm 32 \mathrm{abA}$ & 90 \\
\hline Raw fillet & $145 \pm 14 \mathrm{bA}$ & $120 \pm 11 \mathrm{aA}$ & $38 \pm 08 \mathrm{aB}$ \\
Cooked fillet & $200 \pm 10 \mathrm{aA}$ & $153 \pm 12 \mathrm{bB}$ & $52 \pm 14 \mathrm{bB}$ \\
Raw shells & $194 \pm 14 \mathrm{aA}$ & $145 \pm 9 \mathrm{abB}$ & $40 \pm 15 \mathrm{abC}$ \\
Cooked shells &
\end{tabular}

* Averages followed by the same lower case letter in the same column, and capitalized case letter in equal lines, do not differ statistically at $5 \%$ probability (Tukey test).

Table 5: Ferric Reducing Antioxidant Power (FRAP) of carotenoid extracts of fillet and shells of "Vila Franca" shrimp (Litopenaeus schmitti) (in natura or cooked), from time "zero" or from the storage under different freezing intervals (45 and 90 days).

\begin{tabular}{cccc}
\hline \multirow{2}{*}{ Samples } & \multicolumn{3}{c}{ FRAP- Abs. ${ }_{700 \mathrm{~nm}}$} \\
\cline { 2 - 4 } & \multicolumn{3}{c}{ Freezing time (days) } \\
\cline { 2 - 4 } & $0.275 \pm 0.013 \mathrm{bA}$ & $0.235 \pm 0.041 \mathrm{bA}$ & $0.233 \pm 0.087 \mathrm{bA}$ \\
Raw fillet & $0.253 \pm 0.058 \mathrm{abA}$ & $0.244 \pm 0.041 \mathrm{bA}$ & $0.217 \pm 0.012 \mathrm{bA}$ \\
Cooked fillet & $0.338 \pm 0.062 \mathrm{bA}$ & $0.240 \pm 0.050 \mathrm{bAB}$ & $0.210 \pm 0.018 \mathrm{bB}$ \\
Raw shells & $0.243 \pm 0.024 \mathrm{aA}$ & $0.125 \pm 0.018 \mathrm{aB}$ & $0.126 \pm 0.018 \mathrm{aB}$ \\
\hline Cooked shells & &
\end{tabular}

* Averages followed by the same lower case letter in the same column, and capitalized case letter in equal lines, do not differ statistically at $5 \%$ probability (Tukey test). 
Table 6: Ferric Reducing Antioxidant Power (FRAP), in terms of $\mu \mathrm{g} \mathrm{mL}^{-1}$ equivalents of ascorbic acid, of carotenoid extracts of fillet and shells of "Vila Franca" shrimp (Litopenaeus schmitti) (in natura or cooked), from time "zero" or from the storage under different freezing intervals ( 45 and 90 days).

\begin{tabular}{cccc}
\hline \multirow{2}{*}{ Samples } & \multicolumn{3}{c}{ FRAP of carotenoid extracts in ascorbic acid equivalents $\left(\mu \mathrm{gL}^{-1}\right)$} \\
\cline { 2 - 4 } & 0 & 45 & 90 \\
\cline { 2 - 4 } & $38.19 \pm 1.63 \mathrm{a} \mathrm{A}$ & $33.10 \pm 5.20 \mathrm{bA}$ & $32.84 \pm 11.15 \mathrm{bA}$ \\
Raw fillet & $35.47 \pm 7.41 \mathrm{a} \mathrm{A}$ & $34.25 \pm 5.26 \mathrm{bA}$ & $30.82 \pm 1.48 \mathrm{bA}$ \\
Cooked fillet & $46.27 \pm 8.00 \mathrm{a} \mathrm{A}$ & $33.80 \pm 6.36 \mathrm{bAB}$ & $29.86 \pm 2.32 \mathrm{bB}$ \\
Raw shells & $34.12 \pm 3.11 \mathrm{a} \mathrm{A}$ & $18.96 \pm 2.31 \mathrm{a} \mathrm{B}$ & $19.09 \pm 2.31 \mathrm{a} \mathrm{B}$ \\
Cooked shells & & \multicolumn{3}{c}{ B }
\end{tabular}

* Averages followed by the same lower case letter in the same column, and capitalized case letter in equal lines, do not differ statistically at $5 \%$ probability (Tukey test).

\section{CONCLUSIONS}

According to the present study, the ethanolic extracts of the in natura (fillet and shells) "Vila Franca" shrimp ( $L$. schmitti) are good sources of carotenoids, with outstanding antioxidant activity. Heat treatment resulted in significant decay of the total carotenoid content and antioxidant activity observed by DPPH radical sequestration and through iron reducing power (FRAP) in cooked shells. This change in antioxidant activity was not detected by the ABTS method. Freezing led to losses in the total carotenoid content as well as in the antioxidant activity (measured by the three methods) in the extracts of shrimp shells (with higher concentrations of carotenoids), probably due to oxidation of the compounds during the storage. Even though, the shells of "Vila Franca" shrimp still represent a valuable source of carotenoids, predominantly astaxanthin, whose antioxidant activity was detected even after 90 days of freezing. Despite significant losses of antioxidant activity in each extract obtained from the samples stored 90 days under freezing, the superiority of the antioxidant potential of them compared to ascorbic acid was observed mainly for the cooked fillet and shells. Studies should be conducted to ensure better use of the active compounds of the crustacean, allowing the use of the product as a functional food, which assists in the primary prevention of diseases also generated by oxidative stress.

\section{REFERENCES}

AHMADI, F.; KADIVAR, M.; SHAHEDI, M. Antioxidant activity of Kelussia odoratissima Mozaff: In model and food systems. Food Chemistry. 105:57-64, 2007.

AMBROSIO, C. L. B.; CAMPOS, F. A. C.; FARO, Z. P. Carotenoids as an alternative against hypovitaminosis A. Revista de Nutrição. 19(2):233-243, 2006.
ANDERSEN, H. J. et al. Development of rancidity in salmonoid steaks during retail display. A comparison of practical storage life of wild salmon and farmed rainbow trout. Zeitschrift für LebensmittelUntersuchung und -Forschung. 191(2):119-122, 1990.

ARAÚJO, H. M. P. Distribuição das espécies Paracalanidae (Copepoda. Crustacea) na plataforma continental de Sergipe e Alagoas. Brazilian Journal of Oceanography. 54(4):173181, 2006.

ARMENTA, R. E.; GUERRERO-LEGARRETA, I. Stability studies on astaxanthin extracted from fermented shrimp byoproducts. Journal of Agricultural and Food Chemistry. 57:6095$6100,2009$.

BECERRA, J. A. H. et al. Cholesterol oxidation and astaxanthin degradation in shrimp during Sun drying and storage. Food Chemistry. 145:832-839, 2014.

BERTRAM, J. S.; VINE, A. L. Cancer prevention by retinoids and carotenoids: Independent action on a common target. Biochimica et Biophysica Acta. 1740:170-178, 2005.

BINSAN, W. et al. Antioxidative activity of Mungoong, an extract paste, from the cephalothorax of white shrimp (Litopenaeus vannamei). Food Chemistry. 106:185-193, 2008.

BENJAKUL, S. et al. Effects of flavourzyme on yield and some biological activities of mungoong, an extract paste from the cephalothorax of white shrimp. Journal of Food Science. 74(2):73-80, 2009.

BOON, C. S. et al. Factors influencing the chemical stability of carotenoids in foods. Food Science \& Nutrition. 50(6):515532, 2010.

Ciência e Agrotecnologia 41(1):94-103, Jan/Feb. 2017 
BOSE, K. S.; AGRAWAL, B. K. Effect of lycopene from tomatoes (cooked) on plasma antioxidant enzymes, lipid peroxidation rate and lipid profillet in grade-I hypertension. Annals of Nutrition and Metabolism. 51(5):477-481, 2007.

CHONG, E. W. et al. Dietary antioxidants and primary prevention of age related macular degeneration: Systematic review and meta-analysis. BMJ Case Reports. 13(335):723-729, 2007.

CHOUBERT, G. G.; BRISBARRE, F.; BACCAUNAUD, M. Impact of dietary carotenoid and packaging during frozen storage on the quality of rainbow trout (Oncorhynchus mykiss) fed carotenoids. Journal of the Science of Food and Agriculture. 91(6):1075-82, 2011.

COWARD-KELLY, G.; AGBOGBO, F. K.; HOLTZAPPLE, M. T. Lime treatment of shrimp head waste for the generation of highly digestible animal feed. Carbohydrate Polymers. 97:1515-1520, 2006.

CRUZ, C. D. GENES - A software package for analysis in experimental statistics and quantitative genetics. Acta Scientiarum. 35(3):271-276, 2013.

DUTRA, A. de S. et al. Efeito do tratamento térmico na concentração de carotenóides, compostos fenólicos. Ácido ascórbico e capacidade antioxidante do suco de tangerina murcote. Brazilian Journal of Food Technology. 15(3):198207, 2012.

FAITHONG, N. et al. Chemical composition and antioxidative activity of Thai traditional fermented shrimp and krill products. Food Chemistry. 119:133-140, 2010.

FRANKEL, E. N.; MEYER, A. S. The problems of using onedimensional methods to evaluate multifunctional food and biological antioxidants. Journal of the Science of Food and Agriculture. 80(13):1925-1941, 2000.

HIGUERA-CIAPARA, I.; FÉLIX-VALENZUELA, L.; GOYCOOLEA, F. $M$. Astaxanthin: A review of its chemistry and applications. Critical Reviews in Food Science and Nutrition. 46:185196, 2006.

HUSSEIN, G. et al. Antihypertensive potential and mechanism of action of astaxanthin: III. Antioxidant and histopatological effects in spontaneously hypertensive rats. Biological and Pharmaceutical Bulletin. 29(4):684-688, 2006a.

HUSSEIN, G. et al. Astaxanthin, a carotenoid wtih potential in human health and nutrition. Journal of Natural Products. 69:443-449, 2006b.
JE, J. Y. et al. Antioxidant and angiotensin I converting enzyme inhibitory activity of Bambusae caulis in Liquamen. Food Chemistry. 113:932-935, 2009.

KIM, Y. J.; KIM, Y. A.; YOKOZAWA, T. Protection against oxidative stress. inflammation and apoptosis of high-glucoseexposed proximal tubular epithelial cells by astaxanthin. Journal of Agricultural and Food Chemistry. 57:87938797, 2009.

KUSDIYANTINI, E. et al. Growth kinetics and astaxanthin production of Phaffia rhodozyma on glycerol as a carbon source during batch fermentation. Biotechnology Letters. 20(10):929-934, 1998.

LEVIN, G.; YESHURUN, M.; MOKADY, S. In vivo peroxidative effect of 9-cis-b-carotene compared with that of the all-trans isomer. Cancer et Nutrition. 27:293-297, 1997.

LI, Y. et al. Chemical treatments for reducing the yellow discoloration of channel catfish (Ictalurus punctatus) fillets. Journal of Food Science. 8(10):1609-1613, 2013.

LOBO, V. et al. Free radicals, antioxidants and functional foods: Impact on human health. Pharmacognosy Reviews. 4(8):118-26, 2010.

LYONS, N. M.; O'BRIEN, N. M. Modulatory effects of an algal extract containing astaxanthin on UVA-irradiated cells in culture. Journal of Dermatological Science. 30:73-84, 2002.

MANABE, E. et al. Astaxanthin protects mesangial cells from hyperglycemia-induced oxidative signaling. Journal of Cellular Biochemistry. 103(6):1925-1937, 2008.

MANDEVILLE, S.; YAYLAYAN, V.; SIMPSON, B. K. Proximate analysis, isolation and identification of amino acids and sugars from raw and cooked commercial shrimp waste. Food Biotechnology. 6:51-64, 1992.

MEYERS, S. P. Utilization of shrimp processing waste. Infofish Marketing Digest. 4:18-19, 1986.

MEENATA, K. et al. Antioxidant activity of carotenoprotein isolate from shrimp processing discards. Journal of Aquatic Food Product Technology. 20:209-221, 2011.

MIAO, F. et al. Characterization of astaxanthin esters in Haematococcus pluvialis by liquid chromatographyatmospheric pressure chemical ionization mass spectrometry. Analytical Biochemistry. 352:176-181, 2006.

NIAMNUY, C.; DEVAHASTIN, S.; SOPONRONNARIT, S. Changes in protein compositions and their effects on physical changes of shrimp during boiling in salt solution. Food Chemistry. 108:165-175, 2008b. 
NGUYEN, K. D. Astaxanthin: A comparative case of synthetic versus natural production. Chem. \& Biomol. Engineer. Publ. \& Other Works. 2013. Available in: http://trace.tennessee. edu/cgi/viewcontent.cgi?article $=1094 \&$ context=utk_ chembiopubs. Access in: Sep. 03, 2015.

PALOZZA, P.; KRINSKY, N. I. Astaxanthin and canthaxanthin are potent antioxidants in a membrane model. Archives of Biochemistry and Biophysics. 297(2):291-295, 1992.

PAN, B. S. Recovery of shrimp waste for flavorant. In: VOIGT, M. N.; BOTTA, J. R. (eds.). Advances in fisheries technology and biotechnology for increased profitability. Basel, Switzerland: Technomic Pub., 437-447, 1990.

PARISI, V. et al. Carotenoids and antioxidants in agerelated maculopathy Italian study. Ophthalmology. 115:324-333, 2008.

PASHKOW, F. J.; WATUMULL, D. G.; CAMPBELL, C. L. Astaxanthin: A novel potential treatment for oxidative stress and inflammation in cardiovascular disease. The American Journal of Cardiology. 101:58D-68D, 2008.

PERDIGÃO, N. B. et al. Extração de carotenóides de carapaças de crustáceos em óleo. Boletim Técnico Científico do Centro de Pesquisa e Gestão de Recursos Pesqueiros do Litoral Nordeste. 3(1):234-246, 1995.

PRIOR, R. L.; XIANLI, W.; SCHAICH, K. Standardized methods for determination of antioxidant capacity and phenolics in foods and dietary supplements. Journal of Agricultural and Food Chemistry. 53(10):4290-4302, 2005.

RODRIGUEZ-AMAYA, D. B. Avanços na pesquisa de carotenóides em alimentos: Contribuições de um laboratório brasileiro. Revista do Instituto Adolfo Lutz. 63(2):129-138, 2004.

SANTOS, S. D. et al. Shrimp waste extract and astaxanthin: Rat alveolar macrophage, oxidative stress and inflammation. Journal of Food Science. 77(7):141-146, 2012.

SAS. Statistical Analysis Systems Institute. SAS Online Doc, version 8.02. 2006, SAS Institute Inc., Cary, NC, USA. Available in: http://www.id.unizh.ch/software/unix/statmath/sas/sasdoc/ stat/index.htm. Access in: August, 25, 2015.

$\mathrm{SATOH}, \mathrm{A}$. et al. Preliminary clinical evaluation of toxicity and efficacy of a new astaxanthin-rich Haematococcus pluvialis extract. Journal of Clinical Biochemistry and Nutrition. 44:280-284, 2009.

SCHIEDT, K.; LIAAEN-JENSEN, S. Isolation and analysis. In: BRITTON, G.; PFANDER, H.; LIAAEN-JENSEN, S. (eds.) Isolation and analysis. Basel, Switzerland: Birkhauser Verlag. v.1A. 81-108, 1995.
SEABRA, L. M. J.; PEDROSA, L. F. Astaxanthin: Structural and functional aspects. Revista de Nutrição. 23(6):1041-1050, 2010.

SEABRA, L. M. J. et al. Carotenóides totais em resíduos do camarão Litopenaeus Vannamei. Revista Ceres. 61(1):130133, 2014.

SETNIKAR, I.; SENIN, P.; ROVATI, L. C. Antiatherosclerotic efficacy of policosanol, red yeast rice extract and astaxanthin in the rabbit. Arzneimittelforschung. 55(6):312-317, 2005.

SINGH, R.; DEVI, S.; GOLLEN, R. Role of free radical in atherosclerosis, diabetes and dyslipidaemia: Larger-thanlife. Diabetes/Metabolism Research and Reviews. 31(2):13-26, 2015.

SOWMYA, R. et al. Optimization of enzymatic hydrolysis of shrimp waste for recovery of antioxidant activity rich protein isolate. Journal of Food Science and Technology. 51:3199-207, 2014.

SOWMYA, R.; SACHINDRA, N. M. Evaluation of antioxidant activity of carotenoid extract from shrimp processing byproducts by in vitro assays and in membrane model system. Food Chemistry. 134:308-314, 2012.

SUDARYONO, A.; TSVETNENKO, E.; EVANS, L. H. Digestibility studies on fisheries by-product based diets for Penaeus monodon. Aquaculture. 143:331-340, 1996.

SUH, I. S.; JOO, H-N; LEE, C-G. A novel double-layered photobioreactor for simultaneous Haematococcus pluvialis cell growth and astaxanthin accumulation. Journal of Biotechnology. 125(4):540-546, 2006.

THOMSON, C. A. et al. Plasma and dietary carotenoids are associated with reduced oxidative stress in women previously treated for breast cancer. Cancer Epidemiology Biomarkers \& Prevention. 16(10): 2008-2015, 2007.

VALKO, M. et al. Free radicals, metals and antioxidants in oxidative stress-induced cancer. Chemico-Biological Interactions. 160:1-40, 2006.

WANG, L. L.; XIONG, Y. L. Inhibition of lipid oxidation in cooked beef patties by hydrolyzed potato protein is related to its reducing and radical scavenging ability. Journal of Agricultural and Food Chemistry. 53:91869192, 2005.

WEERATUNGE, W. K. O. V.; PERERA, B. G. K. Formulation of a fish feed for goldfish with natural astaxanthin extracted from shrimp waste. Chemistry Central Journal. 10:4448, 2016.

Ciência e Agrotecnologia 41(1):94-103, Jan/Feb. 2017 